\title{
Novel Insights on Nutrient Management of Sarcopenia in Elderly
}

\author{
Mariangela Rondanelli, Milena Faliva, Francesca Monteferrario, Gabriella Peroni, \\ Erica Repaci, Francesca Allieri, and Simone Perna
}

Department of Public Health, Experimental and Forensic Medicine, School of Medicine, University of Pavia and Endocrinology and Nutrition Unit, Azienda di Servizi alla Persona di Pavia, Via Emilia 12, 27100 Pavia, Italy

Correspondence should be addressed to Mariangela Rondanelli; mariangela.rondanelli@unipv.it

Received 18 August 2014; Revised 16 October 2014; Accepted 19 October 2014

Academic Editor: Giuseppe D’Antona

Copyright (C) 2015 Mariangela Rondanelli et al. This is an open access article distributed under the Creative Commons Attribution License, which permits unrestricted use, distribution, and reproduction in any medium, provided the original work is properly cited.

\begin{abstract}
Sarcopenia is defined as a syndrome characterized by progressive and generalized loss of muscle mass and strength. The more rationale approach to delay the progression of sarcopenia is based on the combination of proper nutrition, possibly associated with the use of dietary supplements and a regular exercise program. We performed a narrative literature review to evaluate the till-now evidence regarding (1) the metabolic and nutritional correlates of sarcopenia; (2) the optimum diet therapy for the treatment of these abnormalities. This review included 67 eligible studies. In addition to the well recognized link between adequate intake of proteins/amino acids and sarcopenia, the recent literature underlines that in sarcopenic elderly subjects there is an unbalance in vitamin D synthesis and in omega-6/omega-3 PUFA ratio. Given the detrimental effect of these metabolic abnormalities, a change in the lifestyle must be the cornerstone in the treatment of sarcopenia. The optimum diet therapy for the sarcopenia treatment must aim at achieving specific metabolic goals, which must be reached through accession of the elderly to specific personalized dietary program aimed at achieving and/or maintaining muscle mass; increasing their intake of fish (4 times/week) or taking omega-3 PUFA supplements; taking vitamin D supplementation, if there are low serum levels.
\end{abstract}

\section{Introduction}

Sarcopenia is defined by the European Working Group on Sarcopenia in Older People (EWGSOP) [1] as a syndrome characterized by progressive and generalized loss of muscle mass and strength. Sarcopenia is a physiological phenomenon that usually starts in the fifth decade. van Kan (2009) has investigated the prevalence of sarcopenia in the population aged $60-70$ years: in this age group, the prevalence ranged from 5 to $13 \%$ but increased to $11-50 \%$ in subjects aged $>80$ years [2].

Sarcopenia becomes responsible not only for the reduction of mobility and the level of autonomy of the elderly, but also for their ability to maintain good health. The functional reduction of the quadriceps muscle predisposes to a limitation in walking, with risk of falls and fractures of the femoral neck. A survey conducted in the USA has estimated the cost-related health consequences of sarcopenia to be 2030 billion dollars [3].
In most elderly patients, the onset of sarcopenia is multifactorial. Like in all body tissues, muscle proteins are subjected to a constant process of synthesis and degradation; in healthy adults (with an adequate protein intake) this turnover is in balance, allowing the maintenance of a positive nitrogen balance and a constant muscle mass $[4,5]$.

In elderly, one of the pathogenic mechanisms leading to sarcopenia is altered muscle protein metabolism: the proteolytic processes are not accompanied by an adequate protein synthesis within the physiological turnover, and muscle cells lose progressively the sensitivity to the anabolic stimulus induced from the essential leucine and IGF-1 (insulin-like growth factor), thus manifesting the so-called "anabolic resistance" [6].

This phenomenon may be associated with other hormonal, functional, and nutritional factors, each of which may contribute to a greater or lesser extent-depending on gender, age, and clinical condition of the patient-to the progression of disease, defined as secondary sarcopenia [7]. 
TABLE 1: Nutrients and drugs that have been shown to present an activity of stimulation in increasing the mass and/or muscle strength in humans or in the animal model.

\begin{tabular}{ll}
\hline & $\begin{array}{l}\text { Proteins and amino acids (BCAAs) and creatine. } \\
\text { Antioxidants (vitamin E, vitamin C, carotenoids, } \\
\text { and resveratrol) } \\
\text { Vutrients } \\
\end{array}$ \\
& Long-chain omega-3 fatty acids \\
\hline Drugs & $\begin{array}{l}\text { Antagonists of mineral corticoids (Spironolactone) } \\
\text { ACE inhibitors }\end{array}$ \\
\hline \multirow{2}{*}{$\begin{array}{l}\text { Hormone } \\
\text { replacement } \\
\text { therapy }\end{array}$} & $\begin{array}{l}\text { Testosterone (T) } \\
\text { Growth hormone (GH) }\end{array}$ \\
& Estrogen \\
& DHEA-S \\
\hline
\end{tabular}

With respect to nutritional causes, about $40 \%$ of subjects $>70$ years do not assume the current RDA (Recommended Dietary Allowances) of proteins $(0.8 \mathrm{~g} / \mathrm{kg} /$ day $)$ [8]. The phenomenon depends upon several factors, each with a variable contribution: these include odontostomatological problems, capable of altering the masticatory function (therefore influencing the choice of foods with reduced content of proteins); a reduced capacity of digestion and assimilation of proteins in enteric tube; delayed gastric emptying, associated with a reduced gallbladder contractility and higher serum levels of the hormone cholecystokinin (CCK) and neuropeptide Y (PYY) (facilitating a long-lasting satiety [9]); a higher blood concentration of leptin in the elderly (showing that the anorexigenic signal prevails over the orexigenic one [10]); a propensity, increasing with age, to take sweet foods, easily chewable and already ready to eat, but not always adequate in the amino acid content.

In addition, costs are an issue, since a greater adherence to the Mediterranean diet is inversely related to BMI but leads to higher cost, which in 2006 were estimated at $1.2 € /$ day [11], due to the higher cost of meat and fish, compared with carbohydrates. Lastly, it is necessary to add that, according to available evidence, current RDA that define the protein intake in the elderly population should be revised, because for a number of reasons-many of which have already been discussed - they are often inadequate in terms of quantity and quality [12-15].

The FAO and the WHO indicate that an intake of 0.75 grams of high quality protein per kilogram of body weight is safe and adequate; however, for elderly subjects, it has been proposed to increase this value to $1.25 \mathrm{~g} / \mathrm{kg} /$ day in order to avoid sarcopenia [16]. It is also necessary to consider that elderly subjects frequently present subclinical nutritional deficits, in particular of vitamins and minerals useful for the muscular tropism, such as vitamin D [17].

The more rational approach to delay the progression of sarcopenia is based on the combination of proper nutrition, possibly associated with the use of supplements and/or foods for special medical purposes, and a regular exercise program. Alternative treatments which are based on administration of hormone preparations such as testosterone, GH, and estrogens are still not universally accepted and require further investigation $[18,19]$. Table 1 lists the nutrients and drugs which have been shown to increase the mass and/or muscle strength in humans or animal models. Table 2 summarizes the studies (prospective cohort studies or randomized controlled trials) performed in elderly subjects to investigate the optimum dietary supplementation, other than proteins/aminoacids, for the treatment of sarcopenia.

Given this background, the aim of the present narrative review is to summarize the state of the art according to the extant literature about two topics: (1) the correct intake of protein and amino acids, in particular branched chain amino acids (BCAAs) need for prevention and treatment of sarcopenia; (2) the correct intake of other nutrients, such as antioxidant, vitamin $\mathrm{D}$, and long-chain omega-3 polyunsaturated fatty acids, or dietary supplements, such as beta-hydroxymethylbutyrate and creatine, in need for prevention and treatment of sarcopenia.

\section{Methods}

The present narrative review was performed following the steps by Egger et al. [20]. Table 3 showed the summary of methodology used. The step were (1) configuration of a working group: three operators skilled in endocrinology and clinical nutrition, of whom one acting as a methodological operator and two participating as clinical operators; (2) formulation of the revision question on the basis of considerations made in the abstract: "the state of the art on metabolic and nutritional correlates of sarcopenia and their nutritional treatment"; (3) identification of relevant studies: a research strategy was planned, on PUBMED (Public MedLine run by the National Center of Biotechnology Information (NCBI) of the National Library of Medicine of Bethesda (USA)), as shown in Table 3; (4) analysis and presentation of the outcomes: the data extrapolated from the revised studies were carried out in the form of a narrative review of the reports and were collocated in tables. The flow diagram of narrative review of the literature has been reported in Figure 1. At the beginning of each section, the keywords considered and the kind of studies chosen have been reported. Suitable for the narrative review were prospective cohort studies, randomized controlled trials (RCT), reviews, meta-analyses, cross sectional studies, and position paper which considered elderly with diagnosis of sarcopenia defined by the European Working Group on Sarcopenia in Older People (EWGSOP) [1].

\section{Results}

3.1. Aminoacids and Protein. This research has been carried out based on the keywords: "sarcopenia" AND "proteins" AND "aminoacids"; 113 articles were sourced. Among them, 1 observation study, 6 reviews, 2 cross sectional studies, 8 randomized controlled studies (RCT), and 1 position paper have been selected and discussed.

It is known that the amino acids, including branched chain amino acids (BCAAs), are necessary for the maintenance of muscle health in the elderly [21]. Approximately 
TABLE 2: Studies (prospective cohort study or randomized controlled trial) performed in elderly subjects to investigate the optimum dietary supplementation, other than proteins, for the treatment of sarcopenia.

\begin{tabular}{|c|c|c|c|c|}
\hline Nutrients & Author & Type of study & Results & Recommended treatment \\
\hline \multirow{3}{*}{ Vitamin D } & $\begin{array}{l}\text { Snijder et al., } 2006 \\
\text { [114] }\end{array}$ & $\begin{array}{l}\text { Prospective } \\
\text { cohort study }\end{array}$ & $\begin{array}{l}\text { Poor vitamin D status is independently } \\
\text { associated with an increased risk of } \\
\text { falling in the elderly, particularly in } \\
\text { those aged } 65-75 \mathrm{yr} \text {. }\end{array}$ & \\
\hline & $\begin{array}{l}\text { Verhaar et al., } 2000 \\
\text { [109] }\end{array}$ & $\begin{array}{l}\text { Randomized } \\
\text { controlled trial }\end{array}$ & $\begin{array}{l}\text { Six months of alphacalcidol treatment } \\
\text { led to a significant increase in the } \\
\text { walking distance over } 2 \text { minutes. }\end{array}$ & $\begin{array}{l}\text { Six months of vitamin D treatment } \\
(0.5 \text { microg alphacalcidol })\end{array}$ \\
\hline & Gloth et al., 1995 [110] & $\begin{array}{l}\text { Randomized } \\
\text { controlled trial }\end{array}$ & $\begin{array}{l}\text { In this cohort of homebound older } \\
\text { people, improvement in vitamin D } \\
\text { status was associated with functional } \\
\text { improvement as measured by the Frail } \\
\text { Elderly Functional Assessment } \\
\text { questionnaire. }\end{array}$ & $\begin{array}{l}\text { One month of therapy with either } \\
\text { placebo or vitamin D (ergo-calciferol) }\end{array}$ \\
\hline $\begin{array}{l}\text { Beta-hydroxy- } \\
\text { beta- } \\
\text { methylbutyrate } \\
\text { (HMB) }\end{array}$ & $\begin{array}{l}\text { Flakoll et al., } 2004 \\
{[50]}\end{array}$ & $\begin{array}{l}\text { Randomized } \\
\text { controlled trial }\end{array}$ & $\begin{array}{l}\text { Daily supplementation of } \mathrm{HMB} \text {, } \\
\text { arginine, and lysine for } 12 \mathrm{wk}\end{array}$ & $\begin{array}{l}\text { Daily supplementation of HMB, } \\
\text { arginine, and lysine for } 12 \text { wk positively } \\
\text { altered measurements of functionality, } \\
\text { strength, fat-free } \\
\text { mass, and protein synthesis, suggesting } \\
\text { that the strategy of targeted nutrition } \\
\text { has the ability to affect muscle health } \\
\text { in elderly women. }\end{array}$ \\
\hline $\begin{array}{l}\text { Long-chain } \\
\text { omega-3 fatty acids }\end{array}$ & S Smith et al., 2011 [131] & $\begin{array}{l}\text { Randomized } \\
\text { controlled trial }\end{array}$ & $\begin{array}{l}\text { Omega- } 3 \text { fatty acid supplementation } \\
\text { had no effect on the basal rate of } \\
\text { muscle protein synthesis but enhanced } \\
\text { the hyperaminoacidemia- } \\
\text { hyperinsulinemia-induced increase in } \\
\text { the rate of muscle protein synthesis, } \\
\text { which was accompanied by greater } \\
\text { increases in muscle mTORSer } 2448 \\
\text { phosphorylation }\end{array}$ & $\begin{array}{l}1.86 \mathrm{~g} \text { eicosapentaenoic acid (EPA, } \\
\text { 20:5n23) and } 1.50 \mathrm{~g} \text { docosahexaenoic } \\
\text { acid (DHA, 22:6n23), both as ethyl } \\
\text { esters }\end{array}$ \\
\hline
\end{tabular}

TABLE 3: Summary of methodology.

\begin{tabular}{lll}
\hline Step & General activities & Specific activities \\
\hline Step 1 & $\begin{array}{l}\text { Configuration of a working } \\
\text { group }\end{array}$ & $\begin{array}{l}\text { Three operators skilled in clinical nutrition: } \\
\text { (i) one operator acting as a methodological operator } \\
\text { (ii) two operators participating as clinical operators }\end{array}$ \\
\hline Step 2 & $\begin{array}{l}\text { Formulation of the revision } \\
\text { question }\end{array}$ & $\begin{array}{l}\text { Evaluation of the state of the art on metabolic and nutritional correlates of sarcopenia and their } \\
\text { nutritional treatment }\end{array}$ \\
\hline & $\begin{array}{l}\text { (a) Definition of the key words (sarcopenia, nutrients, and dietary supplement), allowing the } \\
\text { definition of the interest field of the documents to be searched, grouped in inverted commas } \\
\text { "“..”), and used separately or in combination; }\end{array}$ \\
Step 3 & $\begin{array}{l}\text { Identification of relevant } \\
\text { studies on PUBMED }\end{array}$ & $\begin{array}{l}\text { that allows the establishments of logical relations among concepts; } \\
\text { (c) research modalities: advanced search; } \\
\text { (d) limits: time limits: papers published in the last 20 years; humans; languages: English; } \\
\text { (e) manual search performed by the senior researchers experienced in clinical nutrition } \\
\text { through the revision of reviews and individual articles on sarcopenia in elderly published in } \\
\text { journals qualified in the Index Medicus }\end{array}$ \\
\hline Step 4 & $\begin{array}{l}\text { Analysis and presentation } \\
\text { of the outcomes }\end{array}$ & $\begin{array}{l}\text { The data extrapolated from the revised studies were carried out in the form of a narrative } \\
\text { review of the reports and were collocated in tables. }\end{array}$ \\
\hline
\end{tabular}




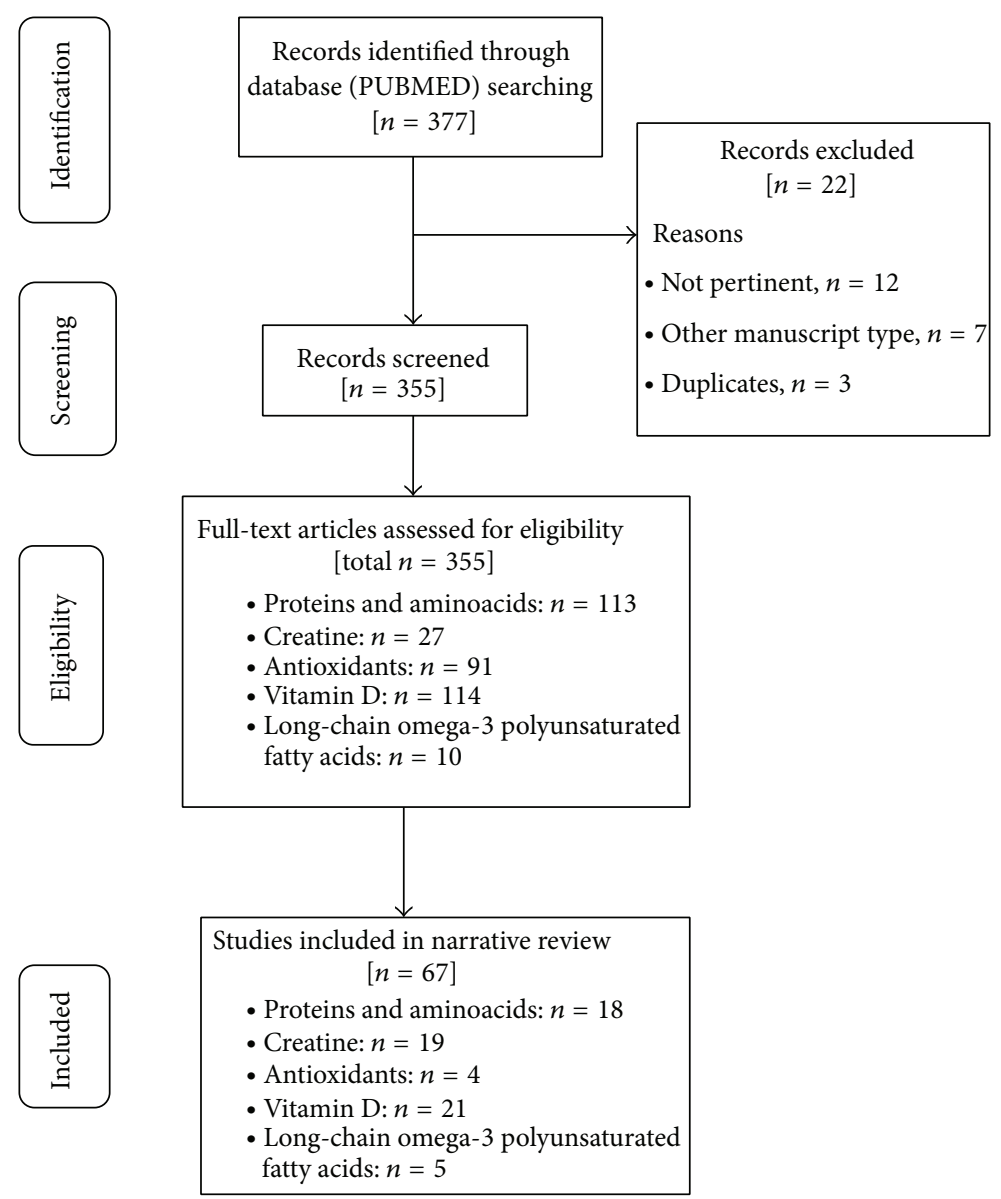

FIGURE 1: Flow diagram of narrative review of literature.

300-600 grams of muscle proteins is degraded and resynthesized daily, with complete renewal of the pool of muscle protein in the human body occurring every 3-4 months. Food intake stimulates muscle protein synthesis, resulting in a positive protein balance. After taking a protein-rich meal, the degree of protein synthesis remains elevated for more than 5 hours, with a peak of 2-3 hours after the intake [22]. It has been shown that in adult subjects a dose of approximately 15-20 grams of protein (or 7.5 grams of essential amino acids) is sufficient to maximize the synthesis of muscle proteins [23].

Probably the elderly, compared with younger subjects, would require a larger amount of protein to obtain the same maximization of protein synthesis, probably 30 grams as shown by Pennings et al. [24]. The bioavailability of amino acids plays a major role in the regulation of protein metabolism in elderly subjects and therefore a nutritional therapy must necessarily aim also at the recovery of muscle and sensitivity to the stimulus induced by the protein-synthetic amino acids, in order to contrast anabolic resistance. Over the past few years, the analysis of the different nutritional strategies has allowed the definition of some key concepts, recently discussed in a position paper by the PROT-AGE Study group [16], which include the recommended amount of protein intake for the healthy elderly; the recommended amount of protein intake for the elderly with acute or chronic conditions; the role of physical activity in association with dietary intake to maintain muscle strength and function in elderly; the practical administration of food proteins (source and quality of dietary protein, protein intake timing, and energy intake).

3.1.1. Recommended Amount of Protein Intake for Healthy Elderly. To maintain and recover the muscle, elderly subjects need to have a greater protein intake compared with younger subjects; older people should have an average intake of protein of $1.2 / \mathrm{g} / \mathrm{kg} /$ day of body weight/day [16]. The threshold for anabolic meal intake of protein/amino acids must be greater in elderly subjects (i.e., 25 to $30 \mathrm{~g}$ of protein per meal, containing approximately $2.5-2.8 \mathrm{~g}$ of leucine), compared with young adults $[24,25]$. The source of protein, timing of intake, and supplementation with amino acid supplements should be considered when making recommendations on the intake of dietary protein in the elderly.

3.1.2. Recommendations in Protein Intake in the Course of Acute and Chronic Pathology. In subjects with pathological conditions, the amount of additional proteins to be taken or the protein requirement depends on the specific disease, its severity, nutritional status of the subject before the onset of the disease, and the impact of the disease on the state of 
nutrition. The majority of elderly patients who present an acute or chronic disease have an increased need for protein intake (1.2 to $1.5 \mathrm{~g} / \mathrm{kg}$ body weight/day), while patients with critical illnesses or severe malnutrition have a need of protein equal to $2 \mathrm{~g} / \mathrm{kg}$ body weight/day. Elderly subjects with severe renal impairment (estimated glomerular filtration rate < $30 \mathrm{~mL} / \mathrm{min} / 1.73 \mathrm{~m}^{2}$ ) who are not on dialysis are an exception and, conversely, must limit their protein intake.

\subsubsection{Quality of Protein and Specific Amino Acids. Not all} dietary proteins have the same kinetic properties: the rate of absorption of dietary amino acids and their effect on the regulation of protein metabolism are dependent on the molecular characteristics of the protein. This characteristic gave rise to the distinction of dietary protein between fast and slow [26-28].

Previous work suggests that whey protein ingestion results in greater postprandial protein retention than does casein ingestion $[29,30]$.

The greater anabolic properties of whey than of casein are mainly attributed to the faster digestion and absorption kinetics of whey, which results in a greater increase in postprandial plasma amino acid availability and thereby further stimulates muscle protein synthesis [23, 26, 27, 31, 32].

Besides differences in protein digestion and absorption kinetics, whey and casein also markedly differ in their amino acid composition $[26,27,32]$.

Whereas both proteins contain all the amino acids required to effectively stimulate muscle protein synthesis [33], whey has a considerably higher leucine content.

As regards differences between animal and vegetal sources, even if previous studies demonstrated that consumption of a meat-containing diet contributed to greater gains in fat-free mass and skeletal muscle mass with resistance training in older men than did a lactoovovegetarian diet [34, 35], more recent studies suggested that increases in muscle strength and size were not influenced by the predominant source of protein consumed by older men with adequate total protein intake [36].

3.1.4. Branched Chain Amino Acids and Leucine. It has been suggested that leucine, which is an essential amino acid belonging to the category of the branched chain amino acids (BCAAs; valine, and together with the isoleucine, whose average requirement is $40 \mathrm{mg} / \mathrm{kg} / \mathrm{day}$ ), is critical to maintaining a healthy muscle tissue and liver. The main sources of leucine are chicken and fish, cottage cheese, lentils, sesame, and peanuts. Unlike many other amino acids, BCAAs are metabolized only in skeletal muscle, since the BCAA aminotransferase enzyme is not present in the liver, the site in which the enzymes metabolizing all other amino acids are present in maximum concentrations, and up to $58 \%$ of all the amino acids ingested (except BCAA) can be oxidized in the liver on the first pass. Skeletal muscle is able to oxidize only 6 amino acids during exercise: in addition to BCAAs, asparagine, aspartate, and glutamate. When combined with exercise training, BCAA supplementation increases testosterone and decreases cortisol to create an anabolic environment [37]. BCAAs represent $14 \%-18 \%$ of the total amino acid content of skeletal muscles [38]. At rest, BCAAs, in particular leucine, have an anabolic effect by increasing protein synthesis and/or a reducing the rate of protein degradation, resulting in a positive net muscle protein balance [39]. The infusion of BCAAs in humans elevates the phosphorylation and the activation of p70S6 kinase and 4E-BP1 in skeletal muscle [40]. Both p70S6 kinase and 4E-BP1 are downstream components of the mTOR signaling pathway, which controls RNA translation and synthesis of proteins, and which is recognized as the central node to support muscle hypertrophy [41]. Leucine is involved in the direct phosphorylation and activation of mTOR in skeletal muscle, further enhancing the protein synthetic response [42]. According to the WHO, for healthy people the daily demand of BCAA to cope with the normal loss in protein metabolism and turnover are the following: valine: $10 \mathrm{mg} / \mathrm{kg}$ body weight; isoleucine: $10 \mathrm{mg} / \mathrm{kg}$ body weight; leucine: $10 \mathrm{mg} / \mathrm{kg}$ body weight [43].

It was recognized that the leucine content of the meal is an important regulator of the synthesis of muscle proteins and influences body composition in the long term [44]. Further research has compared the intake of 10 grams of protein with $18 \%$ of leucine with a similar beverage containing $35 \%$ of leucine, concluding that the beverage with the highest concentration of leucine determines a greater signaling of protein synthesis, resulting in an inferior muscle catabolism by cortisol [45]. Other studies on leucine show that once the minimum requirement of leucine for protein synthesis is satisfied, leucine can be used to activate various signaling pathways, including mTOR. mTOR is a major regulator of protein synthesis, energy sensors, and sensors of nutrients and the availability of amino acids, particularly leucine. The mTOR pathway is activated when ATP levels are high and is blocked when ATP levels are reduced. The activation of mTOR is vital for skeletal muscle hypertrophy. Leucine presents significant activity to stimulate insulin synthesis, which may increase the availability of amino acids for the synthesis of muscle proteins; in addition, leucine inhibits the destruction of muscle proteins with consequent increased balance over time [46]. Although leucine is described as the most important of the three BCAAs, isoleucine and valine also play a role, although they have not shown the same potential as leucine. In fact, the hypertrophy induced by leucine decreases to zero as soon as the presence of the other two BCAAs is poor; regardless of the amount of leucine available to the muscles, muscle growth does not occur if the concentration of the other two BCAAs decreases below a given level [47].

3.1.5. Beta-hydroxy-beta-methylbutyrate. Beta-hydroxy-betamethylbutyrate (HMB) is a product of leucine metabolism that has been shown to slow protein breakdown in muscle tissue [48]. HMB may be effective at limiting the demands placed on the elderly subjects by acute stresses, such as sudden increases in physical activity, an immunologic challenge, or acute malnutrition $[48,49]$.

Daily supplementation of HMB (2 g/day), arginine, and lysine for $12 \mathrm{wk}$ positively altered measurements of functionality, strength, fat-free mass, and protein synthesis, suggesting 
that the strategy of targeted nutrition has the ability to affect muscle health in elderly women [50].

In conclusion, an adequate intake of proteins $(1.2 / \mathrm{g} / \mathrm{kg} /$ day) is essential to prevent sarcopenia and aminoacids supplementation; in particular branched chain amino acids (leucine $2.5 \mathrm{~g} /$ day) as well as the intake of beta-hydroxy butyrate $(2 \mathrm{~g} /$ day $)$ is a well documented intervention for treating sarcopenia.

3.2. Creatine. This research has been carried out based on the keywords: "sarcopenia" AND "creatine"; 27 articles were sourced. Among them, 3 reviews, 11 RCT, 1 single blind study, 1 control case study, 2 observational studies, and 1 cross over study have been selected and discussed.

Creatine is chemically known as a nonprotein nitrogenous compounds; it is a tripeptide composed of three amino acids (glycine, arginine, and methionine). In the human body, creatine is synthesized in the liver and pancreas from the amino acids arginine, glycine, and methionine. Moreover, creatine is present in foods (meat and fish) and is taken with the diet in the amount of 1-2 grams per day. Approximately $95 \%$ of the creatine in the body is stored in skeletal muscles, as phosphocreatine (PCr) for about two-thirds of the total content, while the remaining part is stored as free creatine. The energy provided for the phosphorylation of adenosine diphosphate (ADP) to adenosine triphosphate (ATP) during and after intense exercise largely depends on the amount of $\mathrm{PCr}$ stored in the muscle. With the depletion of $\mathrm{PCr}$ during intense exercise, the availability of energy decreases due to the inability to resynthesize ATP in the amount required to keep the high-intensity exercise [51]. Ageassociated reductions of creatine/phosphocreatine in skeletal muscle have been reported in some studies [52, 53], although not all studies agree $[54,55]$. The reduction of muscle creatine is biologically plausible, due to aging and, possibly, to certain comorbidities, such as sarcopenia, and/or changes with age in behavior (reduced physical activity and/or changes in dietary behaviors, such as decreased intake of meat for edentulous). The type II muscle fibers have a higher content of phosphocreatine compared with type I fibers (86 against and $74 \mathrm{mmol} / \mathrm{kg} \mathrm{dm}$ ) [56], and sarcopenia is characterized by a preferential atrophy of type II fibers [57]. The progressive atrophy of type II fibers may therefore partly explain the reduced muscle creatine in the elderly. Moreover, the reduction of creatine in the muscle of the elderly is in line with previous evidence that documents an increased oxidative process in aged skeletal muscles, for example, with decreased dependence on glycolysis [58] and a decrease of lactate dehydrogenase [59]. Smith et al. (1998) first reported an increase in muscle PCr (30\%) in middle-aged adults (58 years) as a result of short-term intake of high doses of creatine $(0.3 \mathrm{~g} / \mathrm{kg} /$ day for 5 days) [52]. In a similar study, Rawson et al. (2002) reported a smaller increase in muscle phosphocreatine (7 versus 35\%) in older (70 years) compared to younger subjects (24 years), in response to the ingestion of creatine (20 g/day for 5 days) [55]. However, the muscle PCr baseline was greater in the young compared with adult subjects described by Smith et al. (1998) [52], while the elderly subjects described by Rawson et al. (2002) had greater initial muscle
PCr compared with younger subjects [55]. Brose et al. (2003) reported an increase in total muscle creatine $(30 \%$ men, $17 \%$ women) in elderly subjects (70 years) who underwent 14 weeks of resistance training associated with intake of creatine in a dose of $5 \mathrm{~g} /$ day [60], a result that is similar to the increases reported in younger adults [61, 62]. Eijnde et al. (2003) reported an increase in total muscle creatine (5\%) and free creatine (21\%) following 6 months of exercise program for muscular endurance associated with the creatine supplementation (5 g/day) [63]. From these studies, although limited in number, it seems that the muscle creatine in the elderly can be increased with oral creatine supplementation in a dose of $5 \mathrm{~g} /$ day, but that the magnitude of the response can be significantly affected by the initial muscle creatine. Wyss et al. (1998) have suggested that the increase in extracellular creatine may decrease the absorption of creatine muscle by decreasing the activity of creatinine [64]. Although Rawson et al. (2002) have reported the presence of increased creatine in the blood of elderly subjects (elderly $68.5 \mathrm{~mol} / \mathrm{l}$, young $34.9 \mathrm{~mol} / \mathrm{l}$ ) [55], Tarnopolsky et al. (2003) showed no decrease in the activity of creatine after creatine ingestion in older men and women [65]. The most peculiar discovery was an improvement in fatigue resistance, which has been shown in many different studies using different exercise test [52, 66$70]$. Some investigators have reported an increase in strength $[68,69]$, but this has not always been demonstrated $[66,67]$. Importantly, in subsequent publications, researchers have begun to evaluate the performance of activities of daily living (activity daily living, $\mathrm{ADL}$ ) and have shown that creatine supplementation may improve the performance of daily tasks identified in the ADL scale $[69,71,72]$. The improvement of the performance of activities of daily living is an important finding, because of the association between the performance of ADL, fall risk, and mortality. Among the studies that have evaluated the muscle mass, the majority showed a greater increase in lean mass accretion after ingesting creatine in combination with resistance training $[60,73,74]$. A further advantage given by combining creatine supplementation with resistance exercise is the increase in bone mineral content. Chilibeck et al. (2005) showed a greater increase (3.2 versus $1 \%)$ of bone mineral content in older men (71 years) after 12 weeks of creatine supplementation $(0.3 \mathrm{~g} / \mathrm{kg}$ for 5 days, $0.07 \mathrm{~g} / \mathrm{kg}$ for 11 weeks), in combination with training against resistance compared to training alone [75]. Dalbo et al. (2009) have stated that creatine is an effective intervention to combat sarcopenia [76]. The timing of creatine ingestion (i.e., 0.03$0.5 \mathrm{~g} / \mathrm{kg}$ before and after the sessions of resistance training) can be more relevant than the amount of creatine. These novel findings have immediate application for research and health professionals for the design of optimal creatine application strategies for older individuals [51].

In conclusion, an adequate creatine supplementation could represent an intriguing intervention to counteract sarcopenia, in particular fatigue related to sarcopenia, although double-blind, placebo-controlled studies have not been conducted.

3.3. Antioxidants. This research has been carried out based on the keywords: "sarcopenia" AND "antioxidant"; 91 articles 
were sourced. Among them, 1 cross sectional study, 2 reviews, and 1 case control study have been selected and discussed.

Oxidative stress has been implicated as a central mechanism in the pathogenesis of sarcopenia [77].

Oxidative damage in skeletal muscle has been associated with the atrophy and loss of muscle function and fibers in sarcopenia [78].

Moreover, the accumulation of mitochondrial and nuclear DNA damage due to oxidative stress is thought to eventually compromise function, leading to the loss of myocytes [79].

Finally, reactive oxygen species can damage muscle tissue directly, but they also provide a trigger for the expression of inflammatory cytokines such as interleukin- (IL-) 1, tumor necrosis factor (TNF), and IL-6. In older age, a low-grade inflammatory state characterized by increased concentrations of inflammatory cytokines and acute phase proteins is common $[80,81]$.

Studies conducted among community-dwelling older adults suggest that the proinflammatory state does have a long-term consequence for sarcopenia. In the Longitudinal Aging Study Amsterdam, elevated IL-6 and CRP were associated with a loss of muscle strength over three years of followup [82].

Given this background, antioxidants (carotenoids, vitamin E, and vitamin C) should play an important role against sarcopenia.

Carotenoids inactivate free radicals and appear to modulate the transcription factors, such as the NFkB, which are involved in the regulation of IL- 6 and other proinflammatory cytokines and have the ability, like alpha-tocopherol, to increase muscle strength $[83,84]$.

In the Women's Health and Aging Studies (WHAS) I and II, low serum carotenoid levels were associated with poor muscle strength [84]. Likewise in the InCHIANTI study, a low-carotene intake was associated with low physical performance [85]. These observations are consistent with a growing number of studies showing that a diet with high intake of fruits and vegetables is associated with a reduced risk of inflammation, hypertension, diabetes, cardiovascular disease, sarcopenia, and mortality [83].

Adherence to the Mediterranean diet, which is characterized by a high intake of fruits, vegetables, and whole grains, and lower consumption of red meat and saturated fats are associated with lower circulating IL-6 [86], and a recent trial showed the Mediterranean diet reduced IL-6 in adults [87].

In animal models, it was found that the ability of leucine to stimulate muscle protein synthesis is significantly decreased in aged rats compared to young adults. This defect was reversed when the animal was supplemented with antioxidants. The effects may be due to a reduction of the inflammatory state due to the antioxidants themselves [88]. In addition, the supplementation of vitamins $\mathrm{E}$ and $\mathrm{C}$ improves indices of oxidative stress associated with exercise in aged rats [89].

Concerning the specific vitamin E, in human studies, vitamin $\mathrm{E}$ has been shown to affect muscle strength of the elderly [90].
Several studies have shown the positive effects of vitamin $\mathrm{E}$ in reversing muscle damage during extensive muscle contraction (exercise) in healthy men. Vitamin E supplementation at a dose of $800 \mathrm{IU}$ for 28 days resulted in lowering the expression of oxidative stress markers after a downhill run in both young and older men [91].

In another study, a longer supplementation period (12 weeks of vitamin $\mathrm{E}$ supplementation) lowered creatinine kinase level after exercise in young men, whereas older men showed decreased lipid peroxidation in both resting state and after exercise, indicating that vitamin E promotes adaptation against exercise induced-oxidative stress and reduced muscle damage [92].

In animal models, similar results were obtained $[93,94]$.

In conclusion, until today, despite the promising abovementioned animal studies and studies on subjects without sarcopenia, no RCT studies have evaluated the efficacy of an integration with antioxidants in the elderly patient suffering from sarcopenia. These studies are needed, given that recent epidemiological studies in community-dwelling older adults show that low serum/plasma carotenoids are independently associated with low skeletal muscle strength and the development of walking disability.

3.4. Vitamin $D$. This research has been carried out based on the keywords: "sarcopenia" AND "vitamin D"; 114 articles were sourced. Among them, 6 RCT, 5 reviews, 5 observational studies, 4 longitudinal studies, 2 population studies, 2 prospective studies, and 2 cohort analytic studies have been selected and discussed.

Vitamin D deficiency is common among geriatric patients $(2-60 \%)[95,96]$. Vitamin D is hydroxylated in the liver to 25 $(\mathrm{OH}) \mathrm{D}$. This step is still well presented in the elderly, but it can be affected by liver disease [97, 98]. Further hydroxylation occurs in the kidney with the formation of 1,25-(OH2) D; however the activity of hydroxylation by the kidney may decrease with age, in parallel with the decline in renal function [99]. Consequences are the following: a low level of vitamin $\mathrm{D}$, renal failure, and a low intake of calcium may result in mild secondary hyperparathyroidism. Increased levels of parathyroid hormone (PTH) cause an increase in bone turnover that is associated with bone loss, predominantly cortical; secondary hyperparathyroidism has been proposed as the main mechanism through which vitamin D deficiency contributes to the pathogenesis of hip fracture [95]. The presence of receptors for vitamin $\mathrm{D}$ was demonstrated in many organs [100], and the active metabolite, 1,25-2(OH)D, has been shown to be implicated in numerous systems that reduce the cell growth and inducing differentiation [101, 102]. Epidemiological studies have suggested that vitamin $D$ deficiency is associated with cancer of the colon and breast $[103,104]$. Furthermore, the status of vitamin D influences the immune system and insulin secretion [105].

Many studies have shown that low levels of 1,25-(OH) D and $25-(\mathrm{OH}) \mathrm{D}$ are associated with lower muscle strength, increased body instability, falls, and disability in older subjects $[106,107]$. A significant association between the genotypes of the receptor for vitamin $\mathrm{D}$ with the strength of the quadriceps was also observed [108]. In addition, studies on 
vitamin D supplementation in elderly subjects with vitamin $\mathrm{D}$ deficiency showed an improvement in physical function and isometric knee extension versus placebo $[109,110]$. In parallel with the decline in muscle mass and function with aging, there is a reduction of the expression of the receptors VDR (vitamin D receptor) in skeletal muscle [111]. Previous research has linked some VDR polymorphisms with the reduction of muscle mass and function in the elderly [112], suggesting that vitamin D plays a role in the development and progression of sarcopenia [113]. Prospective analysis of LASA (the Longitudinal Aging Study Amsterdam) has shown that low levels of $25 \mathrm{OHD}$ are predictive of an increased risk of recurrent falls at 1 year [114], reduction of muscle mass and strength in 3 years [115], and admission to nursing homes in six years [116]. Limited data suggest that physical activity or hypertrophy of skeletal muscle may be an important source of vitamin D [113]. It has been shown that skeletal muscle is the main deposit of vitamin D in infant rats [117]. The outdoor exercise improves the levels of $25 \mathrm{OHD}$ in the elderly [118]. This suggests that physical activity may influence muscle hypertrophy independently of $25 \mathrm{OHD}$. Pfeifer et al. (2002) suggested that the muscle building exercises can increase the levels of 25OHD [119], but further studies are needed [113]. Studies conducted to evaluate the effects of vitamin $\mathrm{D}$ supplements on functional abilities are partially contradictory. Some studies have shown that vitamin D intake did not improve physical performance $[120,121]$. These studies were conducted in subjects with normal vitamin D. Conversely, studies conducted in 122 elderly subjects with low levels of vitamin $\mathrm{D}$ have been shown to benefit significantly from supplementation of vitamin D. In particular, Dhesi et al. [122] demonstrated in a group of subjects (mean age 77 years), history of falls and blood values of vitamin D less than or equal to 12 micrograms/liter of a daily supplementation with 600 UI ergo-calciferol induced a 3\% improvement of physical performance, as assessed by the "Aggregated Functional Performance Time (AFPT)" [123], while in the control group a $9 \%$ deterioration was reported. With respect to the postural stability, which is related to the state of vitamin D $[124,125]$, the study showed $13 \%$ improvement, while the control group had a worsening equal to $3 \%$. In terms of reaction time, the treated group had a $13 \%$ improvement compared with a deterioration of $3 \%$ of the placebo group. However, it was not demonstrated an improvement in muscle strength [126].

Recently, Muir and Montero-Odasso [127] performed a meta-analysis on a collection of studies that those aged over 60 years participate in randomized control trials of the effect of vitamin D supplementation without an exercise intervention on muscle strength, gait, and balance. The meta-analysis suggests that vitamin D supplementation (800-1000 IU) daily was associated with improvements of muscle strength and balance.

In conclusion, in vitamin $\mathrm{D}$ deficient sarcopenic subjects, dietary vitamin D supplementation (800-1000 IU daily) could be promising and interesting for treatment of sarcopenia.

3.5. Long-Chain Omega-3 Fatty Acids. This research has been carried out based on the keywords: "sarcopenia" AND "omega 3"; 10 articles were sourced. Among them, 2 RCT, 1 review, and 2 case control studies have been selected and discussed.

The ability of the skeletal musculature to use amino acids to build or renew constitutive proteins is gradually lost with age and this is partly due to a decline in skeletal muscle insulin sensitivity. Since long-chain omega-3 polyunsaturated fatty acids (LCn-3PUFA) from fish oil are known to improve insulin-mediated glucose metabolism in insulin-resistant states, some evidence in animal model suggests that polyunsaturated fatty acids might be a potentially useful therapeutic agent for the treatment and prevention of sarcopenia. It has been shown that providing feed enriched in fish oil to growing steers increases the activation (phosphorylation) of anabolic signaling proteins in muscle during administration of insulin and amino acids and increases the nonoxidative whole-body disposal of amino acids, an index of increased whole-body protein synthesis [128].

Furthermore, omega-3 fatty acid supplementation has been shown to prevent loss of muscle mass in burned guinea pigs [129].

In addition, omega-3 fatty acids present anti-inflammatory properties [130], which may also help alleviate the muscle anabolic resistance in older adults.

With respect to the effect of dietary omega- 3 fatty acid supplementation on the rate of muscle protein synthesis and the anabolic signaling cascade in older adults, recently it has been demonstrated that omega-3 fatty acid supplementation had no effect on the basal rate of muscle protein synthesis but enhanced the hyperaminoacidemia-hyperinsulinemiainduced increase in the rate of muscle protein synthesis, which was accompanied by greater increases in muscle mTORSer2448 phosphorylation [131].

In conclusion, dietary LCn-3PUFA supplementation could potentially provide a safe, simple, and low-cost intervention to counteract anabolic resistance and sarcopenia.

\section{Discussion}

The more rational approach to delay the progression of sarcopenia is based on the combination of proper nutrition, possibly associated with the use of dietary supplements and a regular exercise program. An adequate intake of proteins $(1.2 / \mathrm{g} / \mathrm{kg} / \mathrm{day})$ is essential to prevent sarcopenia and aminoacids supplementation, in particular branched chain amino acids, is a well documented intervention for treating sarcopenia. Moreover, the current literature suggests that dietary LCn-3PUFA, vitamin D, and creatine supplementation could potentially provide a safe, simple, and low-cost intervention to counteract anabolic resistance and sarcopenia.

The author's nutritional recommendations have been showed in Table 4.

\section{Conflict of Interests}

The authors declare that there is no conflict of interests regarding the publication of this paper. 
TABLE 4: Effect of nutrients or dietary supplementations on metabolic correlates of sarcopenia.

\begin{tabular}{ll}
\hline Nutrients or dietary supplementations & Recommendations \\
\hline Proteins: average daily intake & It is recommended that the total protein intake should \\
& be $1-1.2 \mathrm{~g} / \mathrm{kg} /$ day $[16]$
\end{tabular}

Proteins: timing of intake

It is recommended to have 30 grams of protein of high biological value for each meal [25]

It is recommended to have whey protein ingestion

Proteins: fast and slow because whey protein ingestion results in greater postprandial protein retention than does casein ingestion [31]

Proteins: animal and vegetal sources

When the total protein intake is adequate, the source of protein consumed (vegetal or animal) does not influence muscle strength and size [36]

Branched chain amino acids (BCAAs), It is recommended to have an adequate daily leucine supplementation ( $3 \mathrm{~g} /$ day)

It is recommended to have a daily intake of beta-hydroxy butyrate (HMB-b, $2 \mathrm{~g}$ /day) because it can attenuate the loss of muscle mass and increase muscle mass and strength [50]

It is recommended to have an adequate creatine supplementation because it could represent an intriguing intervention to counteract sarcopenia and in particular fatigue associated with sarcopenia; the timing of creatine ingestion (i.e., $0.03-0.5 \mathrm{~g} / \mathrm{kg}$ before and after the sessions of resistance training) can be more relevant than the amount of creatine $[73,76]$

It is recommended to have a dietary vitamin $\mathrm{D}$

Vitamin D supplementation (800-1000 UI ergo-calciferol/day) in vitamin D deficient sarcopenic subjects [127]
Specific effect

The elderly, compared with younger

subjects, would require a larger amount of protein to obtain the same maximization of protein synthesis

The greater anabolic properties of whey than of casein are mainly attributed to the faster digestion and absorption kinetics of whey, which results in a greater increase in postprandial plasma amino acid availability and thereby further stimulates muscle protein synthesis. Moreover, whey has a considerably higher leucine content

Increases in muscle strength and size were not influenced by the predominant source of protein consumed by older men with adequate total protein intake

A high proportion of leucine is required for optimal stimulation of the rate of muscle protein synthesis by essential amino acids in the elderly

Beta-hydroxy-beta-methylbutyrate is a product of leucine metabolism that has been shown to slow protein breakdown in muscle tissue

The ingestion of an adequate creatine supplementation determines the increase in muscle phosphocreatine (PCr) and the energy provided for the phosphorylation of adenosine diphosphate (ADP) to adenosine triphosphate (ATP) during and after intense exercise largely depends on the amount of PCr stored in the muscle

Dietary vitamin D supplementation determines an increase of the expression of the receptors VDR (vitamin D receptor) in skeletal muscle

It is recommended to have a diet with high intake of fruits, vegetables whole grains, which is rich in antioxidant, and lower consumption of red meat and saturated fats, because it is associated with a reduced risk of inflammation correlated to oxidative damage [83]
Adherence to the diet rich in antioxidants is associated with lower circulating IL-6 Antioxidants. vitamin E, vit
carotenoids, and resveratrol
It is recommended to have dietary long-chain omega-3

Long-chain omega-3 polyunsaturated fatty acids (LCn-3PUFA) polyunsaturated fatty acids (1.86 g eicosapentaenoic acid and $1.50 \mathrm{~g}$ docosahexaenoic acid/day) supplementation [131]
Long-chain omega-3 polyunsaturated fatty acids (LCn-3PUFA) supplementation improves insulin-mediated glucose metabolism in insulin-resistant states and increases the activation (phosphorylation) of anabolic signaling proteins in muscle during administration of insulin and amino acids and increases the nonoxidative whole-body disposal of amino acids, an index of increased whole-body protein synthesis 


\section{References}

[1] A. J. Cruz-Jentoft, J. P. Baeyens, J. M. Bauer et al., "Sarcopenia: European consensus on definition and diagnosis: report of the European working group on Sarcopenia in older people," Age and Ageing, vol. 39, no. 4, Article ID afq034, pp. 412-423, 2010.

[2] G. A. van Kan, "Epidemiology and consequences of sarcopenia," The Journal of Nutrition, Health and Aging, vol. 13, no. 8, pp. 708-712, 2009.

[3] http://www.iofbonehealth.org/.

[4] W. R. Frontera, V. A. Hughes, R. A. Fielding, M. A. Fiatarone, W. J. Evans, and R. Roubenoff, "Aging of skeletal muscle: a 12-yr longitudinal study," The Journal of Applied Physiology, vol. 88, no. 4, pp. 1321-1326, 2000.

[5] M. J. Delmonico, T. B. Harris, J. S. Lee et al., "Alternative definitions of sarcopenia, lower extremity performance, and functional impairment with aging in older men and women," Journal of the American Geriatrics Society, vol. 55, no. 5, pp. 769774, 2007.

[6] D. Dardevet, D. Rémond, M.-A. Peyron, I. Papet, I. SavaryAuzeloux, and L. Mosoni, "Muscle wasting and resistance of muscle anabolism: the "anabolic threshold concept" for adapted nutritional strategies during sarcopenia," The Scientific World Journal, vol. 2012, Article ID 269531, 6 pages, 2012.

[7] V. Kumar, A. K. Abbas, and J. C. Aster, Eds., Robbins \& Cotran Pathologic Basis of Disease, 2010.

[8] U. Tarantino, G. Cannata, D. Lecce, M. Celi, I. Cerocchi, and R. Iundusi, "Incidence of fragility fractures," Aging Clinical and Experimental Research, vol. 19, no. 4, pp. 7-11, 2007.

[9] V. Di Francesco, M. Zamboni, A. Dioli et al., "Delayed postprandial gastric emptying and impaired gallbladder contraction together with elevated cholecystokinin and peptide YY serum levels sustain satiety and inhibit hunger in healthy elderly persons," Journals of Gerontology-Series A Biological Sciences and Medical Sciences, vol. 60, no. 12, pp. 1581-1585, 2005.

[10] V. di Francesco, M. Zamboni, E. Zoico et al., "Unbalanced serum leptin and ghrelin dynamics prolong postprandial satiety and inhibit hunger in healthy elderly: another reason for the 'anorexia of aging'" The American Journal of Clinical Nutrition, vol. 83, no. 5, pp. 1149-1152, 2006.

[11] H. Schröder, J. Marrugat, and M. I. Covas, "High monetary costs of dietary patterns associated with lower body mass index: a population-based study," International Journal of Obesity, vol. 30, no. 10, pp. 1574-1579, 2006.

[12] P. Y. Cousson, M. Bessadet, E. Nicolas, J.-L. Veyrune, B. Lesourd, and C. Lassauzay, "Nutritional status, dietary intake and oral quality of life in elderly complete denture wearers," Gerodontology, vol. 29, no. 2, pp. e685-e692, 2012.

[13] S. Iuliano, A. Olden, and J. Woods, "Meeting the nutritional needs of elderly residents in aged-care: are we doing enough?" The Journal of Nutrition Health and Aging, vol. 17, no. 6, pp. 503508, 2013.

[14] D. Volkert and C. C. Sieber, "Protein requirements in the elderly," International Journal for Vitamin and Nutrition Research, vol. 81, no. 2-3, pp. 109-119, 2011.

[15] E. Smit, K. M. Winters-Stone, P. D. Loprinzi, A. M. Tang, and C. J. Crespo, "Lower nutritional status and higher food insufficiency in frail older US adults," British Journal of Nutrition, vol. 110, no. 1, pp. 172-178, 2013.

[16] J. Bauer, G. Biolo, T. Cederholm et al., "Evidence-based recommendations for optimal dietary protein intake in older people: a position paper from the PROT-AGE Study Group," Journal of the American Medical Directors Association, vol. 14, no. 8, pp. 542-559, 2013.

[17] J. E. Morley, J. M. Argiles, W. J. Evans et al., "Nutritional recommendations for the management of sarcopenia," Journal of the American Medical Directors Association, vol. 11, no. 6, pp. 391396, 2010.

[18] M. G. Giannoulis, F. C. Martin, K. S. Nair, A. M. Umpleby, and P. Sonksen, "Hormone replacement therapy and physical function in healthy older men. Time to talk hormones?" Endocrine Reviews, vol. 33, no. 3, pp. 314-377, 2012.

[19] S. von Haehling, J. E. Morley, and S. D. Anker, "From muscle wasting to sarcopenia and myopenia: update 2012," Journal of Cachexia, Sarcopenia and Muscle, vol. 3, no. 4, pp. 213-217, 2012.

[20] M. Egger, K. Dickersin, and G. D. Smith, "Problems and limitations in conducting systematic reviews," in Systematic Reviews in Health Care: Meta-Analysis in Context, M. Egger, G. D. Smith, and D. G. Altman, Eds., BMJ Books, London, UK, 2nd edition, 2001.

[21] D. J. Millward, "Sufficient protein for our elders?" The American Journal of Clinical Nutrition, vol. 88, no. 5, pp. 1187-1188, 2008.

[22] D. R. Moore, J. E. Tang, N. A. Burd, T. Rerecich, M. A. Tarnopolsky, and S. M. Phillips, "Differential stimulation of myofibrillar and sarcoplasmic protein synthesis with protein ingestion at rest and after resistance exercise," Journal of Physiology, vol. 587, no. 4, pp. 897-904, 2009.

[23] J. Bohé, A. Low, R. R. Wolfe, and M. J. Rennie, "Human muscle protein synthesis is modulated by extracellular, not intramuscular amino acid availability: a dose-response study," Journal of Physiology, vol. 552, no. 1, pp. 315-324, 2003.

[24] B. Pennings, B. Groen, A. de Lange et al., "Amino acid absorption and subsequent muscle protein accretion following graded intakes of whey protein in elderly men," American Journal of Physiology: Endocrinology and Metabolism, vol. 302, no. 8, pp. E992-E999, 2012.

[25] D. Paddon-Jones and B. B. Rasmussen, "Dietary protein recommendations and the prevention of sarcopenia," Current Opinion in Clinical Nutrition \& Metabolic Care, vol. 12, no. 1, pp. 86-90, 2009.

[26] Y. Boirie, M. Dangin, P. Gachon, M.-P. Vasson, J.-L. Maubois, and B. Beaufrère, "Slow and fast dietary proteins differently modulate postprandial protein accretion," Proceedings of the National Academy of Sciences of the United States of America, vol. 94, no. 26, pp. 14930-14935, 1997.

[27] M. Dangin, Y. Boirie, C. Garcia-Rodenas et al., "The digestion rate of protein is an independent regulating factor of postprandial protein retention," American Journal of Physiology: Endocrinology and Metabolism, vol. 280, no. 2, pp. E340-E348, 2001.

[28] R. Koopman, N. Crombach, A. P. Gijsen et al., "Ingestion of a protein hydrolysate is accompanied by an accelerated in vivo digestion and absorption rate when compared with its intact protein," The American Journal of Clinical Nutrition, vol. 90, no. 1, pp. 106-115, 2009.

[29] M. Dangin, Y. Boirie, C. Guillet, and B. Beaufrère, "Influence of the protein digestion rate on protein turnover in young and elderly subjects," Journal of Nutrition, vol. 132, no. 10, pp. 3228S3233S, 2002.

[30] M. Dangin, C. Guillet, C. Garcia-Rodenas et al., "The rate of protein digestion affects protein gain differently during aging in humans," The Journal of Physiology, vol. 549, no. 2, pp. 635-644, 2003. 
[31] B. Pennings, Y. Boirie, J. M. G. Senden, A. P. Gijsen, H. Kuipers, and L. J. C. Van Loon, "Whey protein stimulates postprandial muscle protein accretion more effectively than do casein and casein hydrolysate in older men," The American Journal of Clinical Nutrition, vol. 93, no. 5, pp. 997-1005, 2011.

[32] J. E. Tang, D. R. Moore, G. W. Kujbida, M. A. Tarnopolsky, and S. M. Phillips, "Ingestion of whey hydrolysate, casein, or soy protein isolate: effects on mixed muscle protein synthesis at rest and following resistance exercise in young men," Journal of Applied Physiology, vol. 107, no. 3, pp. 987-992, 2009.

[33] E. Volpi, H. Kobayashi, M. Sheffield-Moore, B. Mittendorfer, and R. R. Wolfe, "Essential amino acids are primarily responsible for the amino acid stimulation of muscle protein anabolism in healthy elderly adults," The American Journal of Clinical Nutrition, vol. 78, no. 2, pp. 250-258, 2003.

[34] W. W. Campbell, M. L. Barton Jr., D. Cyr-Campbell et al., "Effects of an omnivorous diet compared with a lactoovovegetarian diet on resistance-training-induced changes in body composition and skeletal muscle in older men," The American Journal of Clinical Nutrition, vol. 70, no. 6, pp. 1032-1039, 1999.

[35] D. L. Pannemans, A. J. Wagenmakers, K. R. Westerterp, G. Schaafsma, and D. Halliday, "Effect of protein source and quantity on protein metabolism in elderly women," The American Journal of Clinical Nutrition, vol. 68, no. 6, pp. 1228-1235, 1998.

[36] M. D. Haub, A. M. Wells, M. A. Tarnopolsky, and W. W. Campbell, "Effect of protein source on resistive-training-induced changes in body composition and muscle size in older men," American Journal of Clinical Nutrition, vol. 76, no. 3, pp. 511-517, 2002.

[37] C. P. Sharp and D. R. Pearson, "Amino acid supplements and recovery from high-intensity resistance training," Journal of Strength \& Conditioning Research, vol. 24, no. 4, pp. 1125-1130, 2010.

[38] R. Riazi, L. J. Wykes, R. O. Ball, and P. B. Pencharz, "The total branched-chain amino acid requirement in young healthy adult men determined by indicator amino acid oxidation by use of L$\left[1{ }^{13} \mathrm{C}\right]$ phenylalanine," The Journal of Nutrition, vol. 133, no. 5 , pp. 1383-1389, 2003.

[39] S. R. Kimball and L. S. Jefferson, "Signaling pathways and molecular mechanisms through which branched-chain amino acids mediate translational control of protein synthesis," Journal of Nutrition, vol. 136, no. 1, pp. 227S-231S, 2006.

[40] J. S. Greiwe, G. Kwon, M. L. McDaniel, and C. F. Semenkovich, "Leucine and insulin activate p70 S6 kinase through different pathways in human skeletal muscle," The American Journal of Physiology-Endocrinology and Metabolism, vol. 281, no. 3, pp. E466-E471, 2001.

[41] S. R. Kimball and L. S. Jefferson, "Molecular mechanisms through which amino acids mediate signaling through the mammalian target of rapamycin," Current Opinion in Clinical Nutrition \& Metabolic Care, vol. 7, no. 1, pp. 39-44, 2004.

[42] L. Deldicque, D. Theisen, and M. Francaux, "Regulation of mTOR by amino acids and resistance exercise in skeletal muscle," European Journal of Applied Physiology, vol. 94, no. 1-2, pp. 1-10, 2005.

[43] World Health Organization, "Energy and protein requirements-Technical Report Series," vol. 724, 1985.

[44] L. E. Norton, Leucine is a critical factor determining protein quantity and quality of a complete meal to initiate muscle protein synthesis [Ph.D. thesis], University of Illinois, 2010.

[45] E. L. Glynn, C. S. Fry, M. J. Drummond et al., "Excess leucine intake enhances muscle anabolic signaling but not net protein anabolism in young men and women," Journal of Nutrition, vol. 140, no. 11, pp. 1970-1976, 2010.

[46] J. C. Floyd Jr., S. S. Fajans, S. Pek, C. A. Thiffault, R. F. Knopf, and J. W. Conn, "Synergistic effect of essential amino acids and glucose upon insulin secretion in man., Diabetes, vol. 19, no. 2, pp. 109-115, 1970.

[47] D. K. Layman, "The role of leucine in weight loss diets and glucose homeostasis," Journal of Nutrition, vol. 133, no. 1, pp. 261S-267S, 2003.

[48] S. L. Nissen and N. N. Abumrad, "Nutritional role of the leucine metabolite $\beta$-hydroxy $\beta$-methylbutyrate (HMB)," Journal of Nutritional Biochemistry, vol. 8, no. 6, pp. 300-311, 1997.

[49] N. E. Zanchi, F. Gerlinger-Romero, L. Guimarães-Ferreira et al., "HMB supplementation: clinical and athletic performancerelated effects and mechanisms of action," Amino Acids, vol. 40, no. 4, pp. 1015-1025, 2011.

[50] P. Flakoll, R. Sharp, S. Baier, D. Levenhagen, C. Carr, and S. Nissen, "Effect of $\beta$-hydroxy- $\beta$-methylbutyrate, arginine, and lysine supplementation on strength, functionality, body composition, and protein metabolism in elderly women," Nutrition, vol. 20, no. 5, pp. 445-451, 2004.

[51] D. G. Candow, "Sarcopenia: current theories and the potential beneficial effect of creatine application strategies," Biogerontology, vol. 12, no. 4, pp. 273-281, 2011.

[52] S. A. Smith, S. J. Montain, R. P. Matott, G. P. Zientara, F. A. Jolesz, and R. A. Fielding, "Creatine supplementation and age influence muscle metabolism during exercise," Journal of Applied Physiology, vol. 85, no. 4, pp. 1349-1356, 1998.

[53] W. W. Campbell, L. J. O. Joseph, S. L. Davey, D. Cyr-Campbell, R. A. Anderson, and W. J. Evans, "Effects of resistance training and chromium picolinate on body composition and skeletal muscle in older men," Journal of Applied Physiology, vol. 86, no. 1, pp. 29-39, 1999.

[54] K. E. Conley, S. A. Jubrias, and P. C. Esselman, "Oxidative capacity and ageing in human muscle," Journal of Physiology, vol. 526, no. 1, pp. 203-210, 2000.

[55] E. S. Rawson, P. M. Clarkson, T. B. Price, and M. P. Miles, "Differential response of muscle phosphocreatine to creatine supplementation in young and old subjects," Acta Physiologica Scandinavica, vol. 174, no. 1, pp. 57-65, 2002.

[56] P. A. Tesch, A. Thorsson, and N. Fujitsuka, "Creatine phosphate in fiber types of skeletal muscle before and after exhaustive exercise," Journal of Applied Physiology, vol. 66, no. 4, pp. 17561759, 1989.

[57] J. Lexell and C. C. Taylor, "Variability in muscle fibre areas in whole human quadriceps muscle: Effects of increasing age," Journal of Anatomy, vol. 174, pp. 239-249, 1991.

[58] I. R. Lanza, D. E. Befroy, and J. A. Kent-Braun, "Age-related changes in ATP-producing pathways in human skeletal muscle in vivo," Journal of Applied Physiology, vol. 99, no. 5, pp. 17361744, 2005.

[59] P.-O. Larsson and K. Mosbach, "Affinity precipitation of enzymes," FEBS Letters, vol. 98, no. 2, pp. 333-338, 1979.

[60] A. Brose, G. Parise, and M. A. Tarnopolsky, "Creatine supplementation enhances isometric strength and body composition improvements following strength exercise training in older adults," Journals of Gerontology-Series A Biological Sciences and Medical Sciences, vol. 58, no. 1, pp. 11-19, 2003.

[61] K. Vandenberghe, M. Goris, P. van Hecke, M. van Leemputte, L. Vangerven, and P. Hespel, "Long-term creatine intake is beneficial to muscle performance during resistance training," Journal of Applied Physiology, vol. 83, no. 6, pp. 2055-2063, 1997. 
[62] J. S. Volek, N. D. Duncan, S. A. Mazzetti et al., "Performance and muscle fiber adaptations to creatine supplementation and heavy resistance training," Medicine \& Science in Sports \& Exercise, vol. 31, no. 8, pp. 1147-1156, 1999.

[63] B. O. Eijnde, M. Van Leemputte, M. Goris et al., "Effects of creatine supplementation and exercise training on fitness in men 55-75 yr old," Journal of Applied Physiology, vol. 95, no. 2, pp. 818-828, 2003.

[64] M. Wyss, S. Felber, D. Skladal, A. Koller, C. Kremser, and W. Sperl, "The therapeutic potential of oral creatine supplementation in muscle disease," Medical Hypotheses, vol. 51, no. 4, pp. 333-336, 1998.

[65] M. Tarnopolsky, G. Parise, M.-H. Fu et al., "Acute and moderateterm creatine monohydrate supplementation does not affect creatine transporter mRNA or protein content in either young of elderly humans," Molecular and Cellular Biochemistry, vol. 244, no. 1-2, pp. 159-166, 2003.

[66] E. S. Rawson, M. L. Wehnert, and P. M. Clarkson, "Effects of 30 days of creatine ingestion in older men," European Journal of Applied Physiology and Occupational Physiology, vol. 80, no. 2, pp. 139-144, 1999.

[67] E. S. Rawson and P. M. Clarkson, "Acute creatine supplementation in older men," International Journal of Sports Medicine, vol. 21, no. 1, pp. 71-75, 2000.

[68] J. B. Wiroth, S. Bermon, S. Andreï, E. Dalloz, X. Hébuterne, and C. Dolisi, "Effects of oral creatine supplementation on maximal pedalling performance in older adults," European Journal of Applied Physiology, vol. 84, no. 6, pp. 533-539, 2001.

[69] L. A. Gotshalk, J. S. Volek, R. S. Staron, C. R. Denegar, F. C. Hagerman, and W. J. Kraemer, "Creatine supplementation improves muscular performance in older men," Medicine and Science in Sports and Exercise, vol. 34, no. 3, pp. 537-543, 2002.

[70] J. R. Stout, B. S. Graves, J. T. Cramer et al., "Effects of creatine supplementation on the onset of neuromuscular fatigue threshold and muscle strength in elderly men and women (6486 years)," Journal of Nutrition, Health and Aging, vol. 11, no. 6, pp. 459-464, 2007.

[71] L. A. Gotshalk, W. J. Kraemer, M. A. G. Mendonca et al., "Creatine supplementation improves muscular performance in older women," European Journal of Applied Physiology, vol. 102, no. 2, pp. 223-231, 2008.

[72] S. Cañete, A. F. San Juan, M. Pérez et al., "Does creatine supplementation improve functional capacity in elderly women?" Journal of Strength and Conditioning Research, vol. 20, no. 1, pp. 22-28, 2006.

[73] D. G. Candow and P. D. Chilibeck, "Timing of creatine or protein supplementation and resistance training in the elderly," Applied Physiology, Nutrition and Metabolism, vol. 33, no. 1, pp. 184-190, 2008.

[74] M. Tamopolsky, A. Zimmer, J. Paikin et al., "Creatine monohydrate and conjugated linoleic acid improve strength and body composition following resistance exercise in older adults," PLoS ONE, vol. 2, no. 10, article e991, 2007.

[75] P. D. Chilibeck, M. J. Chrusch, K. E. Chad, K. S. Davison, and D. G. Burke, "Creatine monohydrate and resistance training increase bone mineral content and density in older men," The Journal of Nutrition Health and Aging, vol. 9, no. 5, pp. 352-355, 2005.

[76] V. J. Dalbo, M. D. Roberts, C. M. Lockwood, P. S. Tucker, R. B. Kreider, and C. M. Kerksick, "The effects of age on skeletal muscle and the phosphocreatine energy system: can creatine supplementation help older adults," Dynamic Medicine, vol. 8, no. 1, article 6, 2009.

[77] R. S. Schwartz, C. Weindruch, and R. Weindruch, "Interventions based on the possibility that oxidative stress contributes to sarcopenia," The Journals of Gerontology, Series A: Biological Sciences and Medical Sciences, vol. 50, pp. 157-161, 1995.

[78] D. McKenzie, E. Bua, S. McKiernan, Z. Cao, J. Wanagat, and J. M. Aiken, "Mitochondrial DNA deletion mutations: a causal role in sarcopenia," European Journal of Biochemistry, vol. 269, no. 8, pp. 2010-2015, 2002.

[79] E. Carmeli, R. Coleman, and A. Z. Reznick, “The biochemistry of aging muscle," Experimental Gerontology, vol. 37, no. 4, pp. 477-489, 2002.

[80] J. E. Morley and R. N. Baumgartner, "Cytokine-related aging process," Journals of Gerontology Series A: Biological Sciences and Medical Sciences, vol. 59, no. 9, pp. M924-M929, 2004.

[81] K. S. Krabbe, M. Pedersen, and H. Bruunsgaard, "Inflammatory mediators in the elderly," Experimental Gerontology, vol. 39, no. 5, pp. 687-699, 2004.

[82] L. A. Schaap, S. M. F. Pluijm, D. J. H. Deeg, and M. Visser, "Inflammatory markers and loss of muscle mass (sarcopenia) and strength," The American Journal of Medicine, vol. 119, no. 6, pp. 526.e9-526.e17, 2006.

[83] R. D. Semba, F. Lauretani, and L. Ferrucci, "Carotenoids as protection against sarcopenia in older adults," Archives of Biochemistry and Biophysics, vol. 458, no. 2, pp. 141-145, 2007.

[84] R. D. Semba, C. Blaum, J. M. Guralnik, D. T. Moncrief, M. O. Ricks, and L. P. Fried, "Carotenoid and vitamin E status are associated with indicators of sarcopenia among older women living in the community," Aging Clinical and Experimental Research, vol. 15, no. 6, pp. 482-487, 2003.

[85] M. Cesari, M. Pahor, B. Bartali et al., "Antioxidants and physical performance in elderly persons: the Invecchiare in Chianti (InCHIANTI) study," The American Journal of Clinical Nutrition, vol. 79, no. 2, pp. 289-294, 2004.

[86] C. Chrysohoou, D. B. Panagiotakos, C. Pitsavos, U. N. Das, and C. Stefanadis, "Adherence to the Mediterranean diet attenuates inflammation and coagulation process in healthy adults: the ATTICA study," Journal of the American College of Cardiology, vol. 44, no. 1, pp. 152-158, 2004.

[87] K. Esposito, R. Marfella, M. Ciotola et al., "Effect of a Mediterranean-style diet on endothelial dysfunction and markers of vascular inflammation in the metabolic syndrome: a randomized trial," The Journal of the American Medical Association, vol. 292, no. 12, pp. 1440-1446, 2004.

[88] B. Marzani, M. Balage, A. Vénien et al., "Antioxidant supplementation restores defective leucine stimulation of protein synthesis in skeletal muscle from old rats," Journal of Nutrition, vol. 138, no. 11, pp. 2205-2211, 2008.

[89] M. J. Ryan, H. J. Dudash, M. Docherty et al., "Vitamin E and C supplementation reduces oxidative stress, improves antioxidant enzymes and positive muscle work in chronically loaded muscles of aged rats," Experimental Gerontology, vol. 45, no. 11, pp. 882-895, 2010.

[90] A. Ble, A. Cherubini, S. Volpato et al., "Lower plasma vitamin E levels are associated with the frailty syndrome: the InCHIANTI study," Journals of Gerontology A: Biological Sciences and Medical Sciences, vol. 61, no. 3, pp. 278-283, 2006.

[91] M. Meydani, W. J. Evans, G. Handelman et al., "Protective effect of vitamin $\mathrm{E}$ on exercise-induced oxidative damage in 
young and older adults," The American Journal of PhysiologyRegulatory Integrative and Comparative Physiology, vol. 264, no. 5, pp. R992-R998, 1993.

[92] J. M. Sacheck, P. E. Milbury, J. G. Cannon, R. Roubenoff, and J. B. Blumberg, "Effect of vitamin E and eccentric exercise on selected biomarkers of oxidative stress in young and elderly men," Free Radical Biology and Medicine, vol. 34, no. 12, pp. 1575-1588, 2003.

[93] S. A. Devi, S. Prathima, and M. V. V. Subramanyam, "Dietary vitamin E and physical exercise: I. Altered endurance capacity and plasma lipid profile in ageing rats," Experimental Gerontology, vol. 38, no. 3, pp. 285-290, 2003.

[94] S. P. Lee, G. Y. Mar, and L. T. Ng, "Effects of tocotrienol-rich fraction on exercise endurance capacity and oxidative stress in forced swimming rats," European Journal of Applied Physiology, vol. 107, no. 5, pp. 587-595, 2009.

[95] P. Lips, "Vitamin D deficiency and secondary hyperparathyroidism in the elderly: consequences for bone loss and fractures and therapeutic implications," Endocrine Reviews, vol. 22, no. 4, pp. 477-501, 2001.

[96] J.-C. Souberbielle, C. Cormier, C. Kindermans et al., "Vitamin $\mathrm{D}$ status and redefining serum parathyroid hormone reference range in the elderly," Journal of Clinical Endocrinology and Metabolism, vol. 86, no. 7, pp. 3086-3090, 2001.

[97] R. K. Skinner, S. Sherlock, R. G. Long, and M. R. Wills, "25-hydroxylation of vitamin D in primary biliary cirrhosis," The Lancet, vol. 1, no. 8014, pp. 720-721, 1977.

[98] K. Farrington, R. K. Skinner, Z. Varghese, and J. F. Moorhead, "Hepatic metabolism of vitamin D in chronic renal failure," The Lancet, vol. 1, no. 8111, p. 321, 1979.

[99] J. C. Gallagher, B. L. Riggs, J. Eisman, A. Hamstra, S. B. Arnaud, and H. F. DeLuca, "Intestinal calcium absorption and serum vitamin $\mathrm{D}$ metabolites in normal subjects and osteoporotic patients. Effect of age and dietary calcium," Journal of Clinical Investigation, vol. 64, no. 3, pp. 729-736, 1979.

[100] H. Reichel and A. W. Norman, "Systemic effects of vitamin D," Annual Review of Medicine, vol. 40, pp. 71-78, 1989.

[101] M. R. Walters, "Newly identified actions of the vitamin D endocrine system," Endocrine Research, vol. 18, no. 4, pp. 719-764, 1992.

[102] H. A. Pols, J. C. Birkenhager, J. A. Foekens, and J. P. van Leeuwen, "Vitamin D: a modulator of cell proliferation and differentiation," The Journal of Steroid Biochemistry and Molecular Biology, vol. 37, no. 6, pp. 873-876, 1990.

[103] C. Garland, R. B. Shekelle, E. Barrett-Connor, M. H. Criqui, A. H. Rossof, and O. Paul, "Dietary vitamin D and calcium and risk of colorectal cancer: a 19-year prospective study in men," The Lancet, vol. 1, no. 8424, pp. 307-309, 1985.

[104] F. C. Garland, C. F. Garland, E. D. Gorham, and J. F. Young, "Geographic variation in breast cancer mortality in the United States: a hypothesis involving exposure to solar radiation," Preventive Medicine, vol. 19, no. 6, pp. 614-622, 1990.

[105] B. L. Nyomba, R. Bouillon, and P. de Moor, "Influence of vitamin D status on insulin secretion and glucose tolerance in the rabbit," Endocrinology, vol. 115, no. 1, pp. 191-197, 1984.

[106] H. A. Bischoff, H. B. Stahelin, N. Urscheler et al., "Muscle strength in the elderly: its relation to vitamin D metabolites," Archives of Physical Medicine and Rehabilitation, vol. 80, no. 1, pp. 54-58, 1999.

[107] J. K. Dhesi, L. M. Bearne, C. Moniz et al., "Neuromuscular and psychomotor function in elderly subjects who fall and the relationship with vitamin D status," Journal of Bone and Mineral Research, vol. 17, no. 5, pp. 891-897, 2002.

[108] P. Geusens, C. Vandevyver, J. Vanhoof, J.-J. Cassiman, S. Boonen, and J. Raus, "Quadriceps and grip strength are related to vitamin D receptor genotype in elderly nonobese women," Journal of Bone and Mineral Research, vol. 12, no. 12, pp. 20822088, 1997.

[109] H. J. J. Verhaar, M. M. Samson, P. A. F. Jansen, P. L. de Vreede, J. W. Manten, and S. A. Duursma, "Muscle strength, functional mobility and vitamin D in older women," Aging Clinical and Experimental Research, vol. 12, no. 6, pp. 455-460, 2000.

[110] F. M. Gloth III, C. M. Gundberg, B. W. Hollis, J. G. Haddad Jr., and J. D. Tobin, "Vitamin D deficiency in homebound elderly persons," Journal of the American Medical Association, vol. 274, no. 21, pp. 1683-1686, 1995.

[111] H. A. Bischoff-Ferrari, M. Borchers, F. Gudat, U. Dürmüller, H. B. Stähelin, and W. Dick, "Vitamin D receptor expression in human muscle tissue decreases with age," Journal of Bone and Mineral Research, vol. 19, no. 2, pp. 265-269, 2004.

[112] S. M. Roth, J. M. Zmuda, J. A. Cauley, P. R. Shea, and R. E. Ferrell, "Vitamin D receptor genotype is associated with fat-free mass and sarcopenia in elderly men," Journals of Gerontology Series A Biological Sciences and Medical Sciences, vol. 59, no. 1, pp. 10-15, 2004.

[113] D. Scott, L. Blizzard, J. Fell, C. Ding, T. Winzenberg, and G. Jones, "A prospective study of the associations between 25-hydroxy-vitamin D, sarcopenia progression and physical activity in older adults," Clinical Endocrinology, vol. 73, no. 5, pp. 581-587, 2010.

[114] M. B. Snijder, N. M. Van Schoor, S. M. F. Pluijm, R. M. Van Dam, M. Visser, and P. Lips, "Vitamin D status in relation to one-year risk of recurrent falling in older men and women," Journal of Clinical Endocrinology and Metabolism, vol. 91, no. 8, pp. 29802985, 2006.

[115] M. Visser, D. J. H. Deeg, and P. Lips, "Low Vitamin D and high parathyroid hormone levels as determinants of loss of muscle strength and muscle mass (sarcopenia): the longitudinal aging study Amsterdam," Journal of Clinical Endocrinology and Metabolism, vol. 88, no. 12, pp. 5766-5772, 2003.

[116] M. Visser, D. J. H. Deeg, M. T. E. Puts, J. C. Seidell, and P. Lips, "Low serum concentrations of 25-hydroxyvitamin D in older persons and the risk of nursing home admission," The American Journal of Clinical Nutrition, vol. 84, no. 3, pp. 616-622, 2006.

[117] M. R. Clements and D. R. Fraser, "Vitamin D supply to the rat fetus and neonate," The Journal of Clinical Investigation, vol. 81, no. 6, pp. 1768-1773, 1988.

[118] R. Scragg and C. A. Camargo Jr., "Frequency of leisure-time physical activity and serum 25-hydroxyvitamin D levels in the US population: results from the third national health and nutrition examination survey," American Journal of Epidemiology, vol. 168, no. 6, pp. 577-586, 2008.

[119] M. Pfeifer, B. Begerow, and H. W. Minne, "Vitamin D and muscle function," Osteoporosis International, vol. 13, no. 3, pp. 187194, 2002.

[120] O. H. Sørensen, B. Lund, B. Saltin et al., "Myopathy in bone loss of ageing: improvement by treatment with $1 \alpha$-hydroxycholecalciferol and calcium," Clinical Science, vol. 56, no. 2, pp. 157161, 1979.

[121] A. M. Kenny, B. Biskup, B. Robbins, G. Marcella, and J. A. Burleson, "Effects of vitamin D supplementation on strength, 
physical function, and health perception in older, communitydwelling men," Journal of the American Geriatrics Society, vol. 51, no. 12, pp. 1762-1767, 2003.

[122] J. K. Dhesi, S. H. D. Jackson, L. M. Bearne et al., "Vitamin D supplementation improves neuromuscular function in older people who fall," Age and Ageing, vol. 33, no. 6, pp. 589-595, 2004.

[123] M. V. Hurler, J. Rees, and D. J. Newham, "Quadriceps function, proprioceptive acuity and functional performance in healthy young, middle-aged and elderly subjects," Age and Ageing, vol. 27, no. 1, pp. 55-62, 1998.

[124] S. R. Lord, P. N. Sambrook, C. Gilbert et al., "Postural stability, falls and fractures in the elderly: results from the dubbo osteoporosis epidemiology study," Medical Journal of Australia, vol. 160, no. 11, pp. 688-691, 1994.

[125] T. Nguyen, P. Sambrook, P. Kelly et al., "Prediction of osteoporotic fractures by postural instability and bone density," British Medical Journal, vol. 307, no. 6912, pp. 1111-1115, 1993.

[126] E. Sohl, R. T. de Jongh, A. C. Heijboer et al., "Vitamin D status is associated with physical performance: the results of three independent cohorts," Osteoporosis International, vol. 24, no. 1, pp. 187-196, 2013.

[127] S. W. Muir and M. Montero-Odasso, "Effect of vitamin D supplementation on muscle strength, gait and balance in older adults: a systematic review and meta-analysis," Journal of the American Geriatrics Society, vol. 59, no. 12, pp. 2291-2300, 2011.

[128] A.-A. Gingras, P. J. White, P. Y. Chouinard et al., "Long-chain omega-3 fatty acids regulate bovine whole-body protein metabolism by promoting muscle insulin signalling to the AktmTOR-S6K1 pathway and insulin sensitivity," Journal of Physiology, vol. 579, no. 1, pp. 269-284, 2007.

[129] J. W. Alexander, H. Saito, O. Trocki, and C. K. Ogle, "The importance of lipid type in the diet after burn injury," Annals of Surgery, vol. 204, no. 1, pp. 1-8, 1986.

[130] J. W. Fetterman Jr. and M. M. Zdanowicz, "Therapeutic potential of $\mathrm{n}-3$ polyunsaturated fatty acids in disease," The American Journal of Health-System Pharmacy, vol. 66, no. 13, pp. 11691179, 2009.

[131] G. I. Smith, P. Atherton, D. N. Reeds et al., "Dietary omega-3 fatty acid supplementation increases the rate of muscle protein synthesis in older adults: a randomized controlled trial," The American Journal of Clinical Nutrition, vol. 93, no. 2, pp. 402412, 2011. 

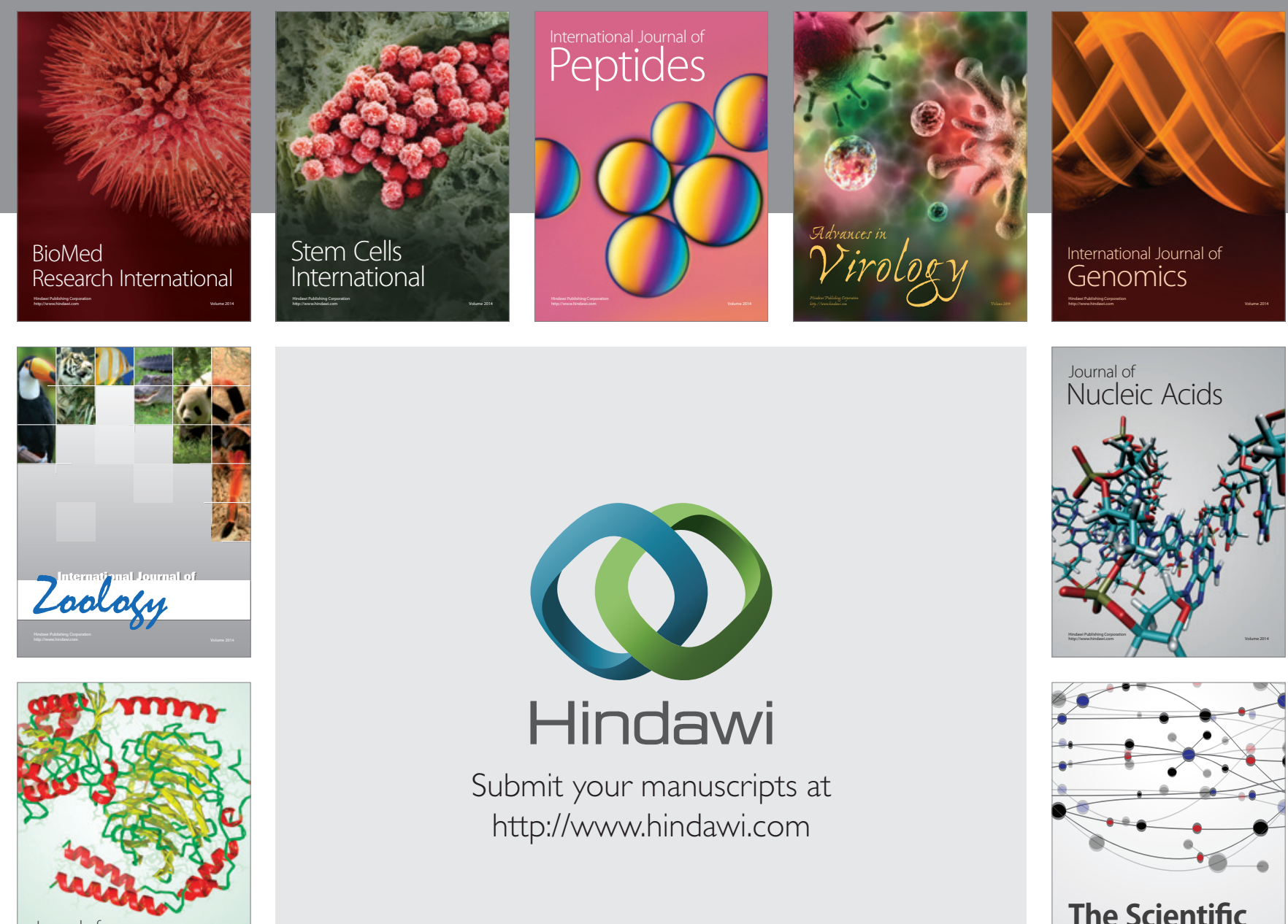

Submit your manuscripts at

http://www.hindawi.com

Journal of
Signal Transduction
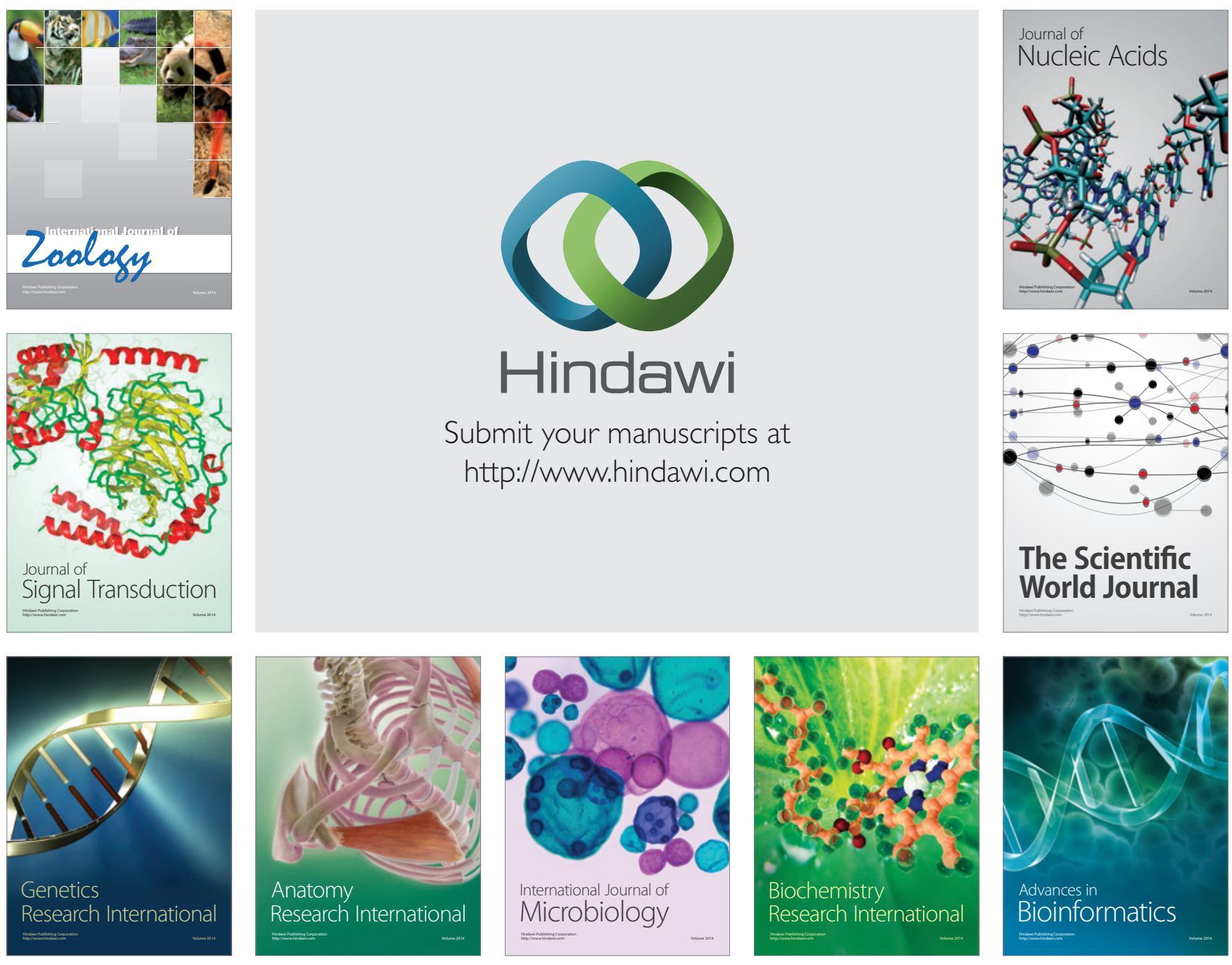

The Scientific World Journal
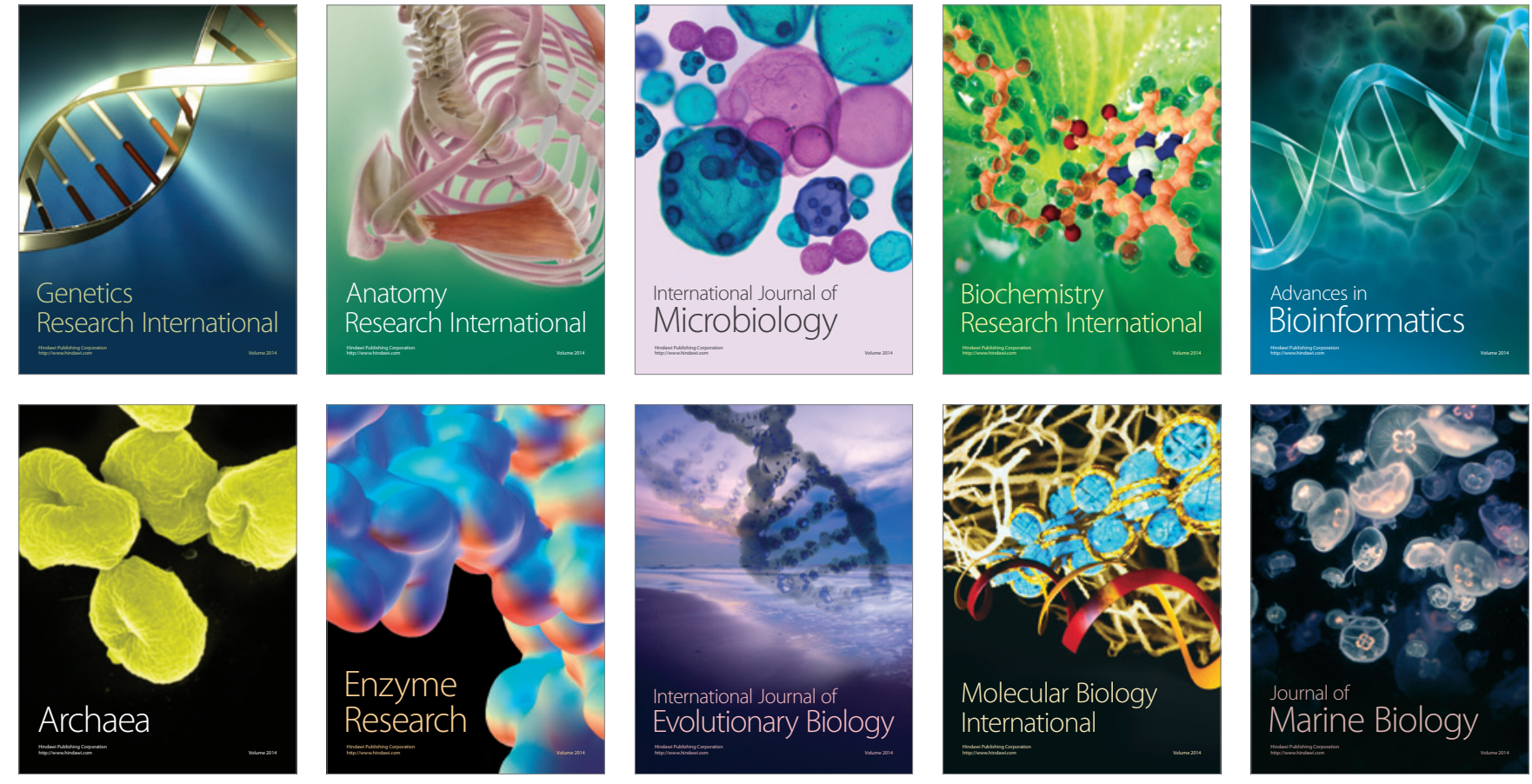